\title{
Metachronous Malignant Mesothelioma and Pulmonary Adenocarcinoma
}

\section{Metakron Malign Mezotelyoma ve Pulmoner Adenokarsinom}

\author{
İrem Hicran ÖZBUDAK', Ömer ÖZBUDAK², Gökhan ARSLAN³ , Abdullah ERDOĞAN', Gülay ÖZBiLíM' \\ Departments of ${ }^{1}$ Pathology, ${ }^{2}$ Pulmonary Medicine, ${ }^{3}$ Radiology and ${ }^{4}$ Chest Surgery, Akdeniz University, Faculty of Medicine, ANTALYA, TURKEY
}

\begin{abstract}
The prevalence of multiple primary malignant neoplasms in a single patient is reported in a wide variation. The co-existence of malignant mesothelioma and pulmonary carcinoma is a rare entity. Herein, we reported a 60-year-old man who was a retired employee and heavy smoker. He had a suspicious history of asbestos exposure. He complained of chest pain and computerized tomography revealed a mass in the lower lobe of left lung. The patient underwent a left lower lobectomy and was diagnosed as pulmonary adenocarcinoma. During follow-up two years after surgery, the patient complained of dyspnea and chest computerized tomography scan revealed right pleural effusion and diffuse pleural thickening. For the differential diagnosis, the patient underwent wedge biopsy from the right lower lobe and was diagnosed as epithelial diffuse malignant mesothelioma. The development of malignant pleural mesothelioma and lung carcinoma could be associated with asbestos exposure. However, a history of asbestos exposure is not required for the diagnosis. The influence of effective anticancer therapies that improve the survival rates and increase the population ages could be related to the occurrence of a second malignancy.
\end{abstract}

Key Words: Metachronous neoplasms, Mesothelioma, Lung adenocarcinoma

\begin{abstract}
ÖZ
Bir hastada izlenen çoklu primer malign neoplazilerin prevalansı değişen oranlarda bildirilmiştir. Malign mezotelyoma ve pulmoner karsinomun birlikteliği ise nadir görülen bir antitedir. Olgumuz 60 yaşında emekli memur olan bir erkek hastadır. Ağır sigara içiciliği ve şüpheli asbest maruziyeti öyküsü vardır. Gögüs ağrısı ile başvurmuş ve bilgisayarlı tomografisinde sol akciğer alt lobda kitle tespit edilmiştir. Hastaya sol alt lobektomi uygulanmış ve pulmoner adenokarsinom olarak tanı almıştır. Bu cerrahiden 2 yıl sonra, takibinde hastanın nefes darlığg şikayeti üzerine, bilgisayarlı tomografisinde sağda plevral efüzyon ve difüz plevral kalınlaşma bulunmuştur. Hastaya ayırıcı tanı için sağ akciğer alt lob kama biyopsi uygulanmış ve epitelyal difüz malign mezotelyoma tanısı verilmiştir. Malign plevral mezotelyoma ve akciğer karsinomu gelişimi asbest maruziyeti ile ilişkili olabilir. Ancak tanı için asbest maruziyet öyküsünün olması gerekli değildir. Etkili antikanser tedavileri ile yaşam oranlarının yükselmesi ve popülasyon yaşının artması kişide ikinci malignitenin ortaya çıkması ile ilişkili olabilir.
\end{abstract}

Anahtar Sözcükler: Farklı zamanlarda oluşan tümörler, Mezotelyoma, Akciğer adenokarsinomu

\section{INTRODUCTION}

The first report of multiple primary malignant neoplasms in an individual patient was published at the end of the $19^{\text {th }}$ century. Since then, several papers worldwide have addressed this issue and the prevalence of multiple primary malignant neoplasms reported varies from $0.734 \%$ to $11.7 \%(1,2)$. However, reports from Turkey indicated the prevalence to be between $0.828 \%$ and $1.03 \%(3,4)$.

The etiopathogenesis of multiple neoplasms includes hereditary aspects, the influence of environmental agents, previous therapies and tumor-producing hormones (5-8). Multiple neoplasms could be defined by when they occur

(Turk Patoloji Derg 2013, 29:83-86)

Received : 31.01.2011 Accepted : 03.02.2011 as synchronous and metachronous. The latter is applied for the neoplasms appearing in a single patient with an interval more than 6 months (9).

The co-existence of malignant mesothelioma and pulmonary carcinoma is a rare entity and generally such reports regard single cases and series with a small number of cases in the English literature (10-15). Moreover, this co-existence has been reported in patients with significant exposure to asbestos. Herein, we report a rare case of metachronous malignant mesothelioma and pulmonary carcinoma with a suspicious history of asbestos exposure.

Correspondence: İrem Hicran ÖZBUDAK

Department of Pathology, Akdeniz University, Faculty of Medicine,

ANTALYA, TURKEY

E-mail: iremhicrang@hotmail.com Phone: +90 5052589848 


\section{CASE REPORT}

A 60-year-old man was admitted to the hospital with a history of chest pain, dry cough, dyspnea and malaise for two months. He was a retired employee and heavy smoker (40 pack years). He had a suspicious history of asbestos exposure because of the house that he had lived in during his childhood. On physical examination, diminished breath sounds were found in the left lung. The chest computerized tomography (CT) revealed a mass with spicular projections in the lower lobe of left lung (Figure 1). On fiberbronchoscopy, no endobronchial lesion was detected. The patient underwent a left lower lobectomy. The tumor was firm, grayish-white, $5.5 \times 4.5 \mathrm{~cm}$ in size and composed of pleomorphic, atypical epithelial cells forming solid

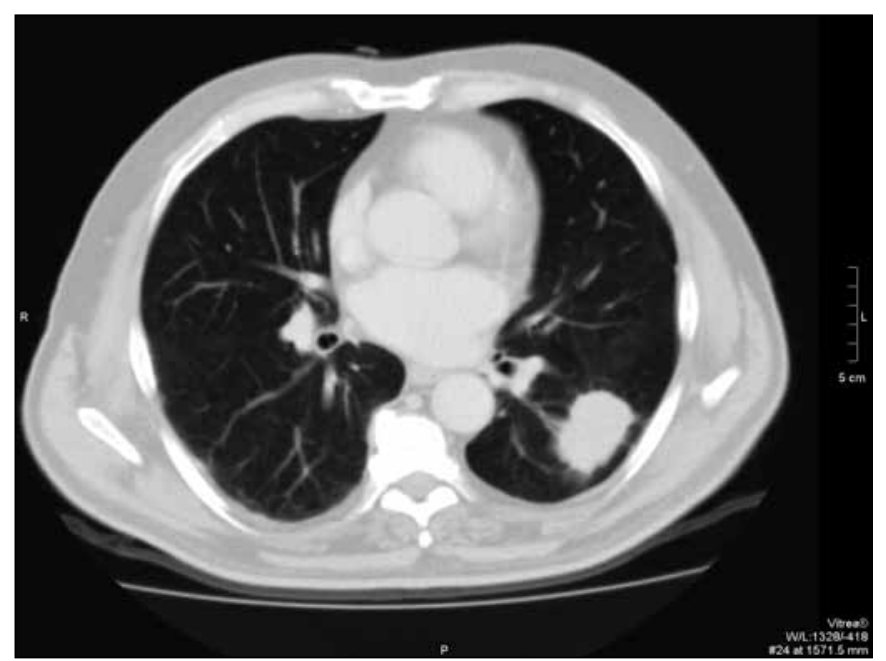

Figure 1: The parenchyma window of chest computerized tomography revealed a tumor with spicular projections in the lower lobe of left lung. areas. Tumor cells had mucin-positive intracytoplasmic droplets and the immunohistochemistry showed tumor cells positive for Cytokeratin 7, Carcinoembryonic antigen (CEA) and Thyroid transcription factor-1 (TTF-1) (Figure $2 \mathrm{~A}, \mathrm{~B})$. The patient was diagnosed as lung adenocarcinoma with these findings. He had been treated with cisplatin and vinorelbine for six months. During follow-up two years after surgery, the patient complained of dyspnea and chest CT scan revealed right pleural effusion and diffuse pleural thickening with irregular and often nodular internal margin at the right mediastinal pleura (Figure 3). Differential diagnosis included metastasis of lung adenocarcinoma and primary tumor of pleura. The patient underwent wedge biopsy from right lower lobe. Histologically, the malignant epithelioid cells were arranged in sheets and cords. Diffuse immunopositivity was detected with Calretinin and Cytokeratin 5/6 in tumor cells; however, TTF-1 and CEA were negative (Figure $4 \mathrm{~A}, \mathrm{~B}$ ). The patient was diagnosed as epithelial diffuse malignant mesothelioma.

\section{DISCUSSION}

In the diagnosis of multiple primary malignant neoplasms, Warren and Gates established three criteria; (1) each of the tumors must have a definite features of malignancy, (2) each must be distinct, and (3) the probability of one being a metastasis of the other must be excluded (16). By this definition, our patient had two different primary malignant neoplasms. The prevalence widely varies as mentioned above between the reports worldwide and from Turkey. This variation may be caused by several factors such as the criteria to define multiple primaries in a case. Also the case series whether from clinical or autopsy could change the prevalence (1-4).
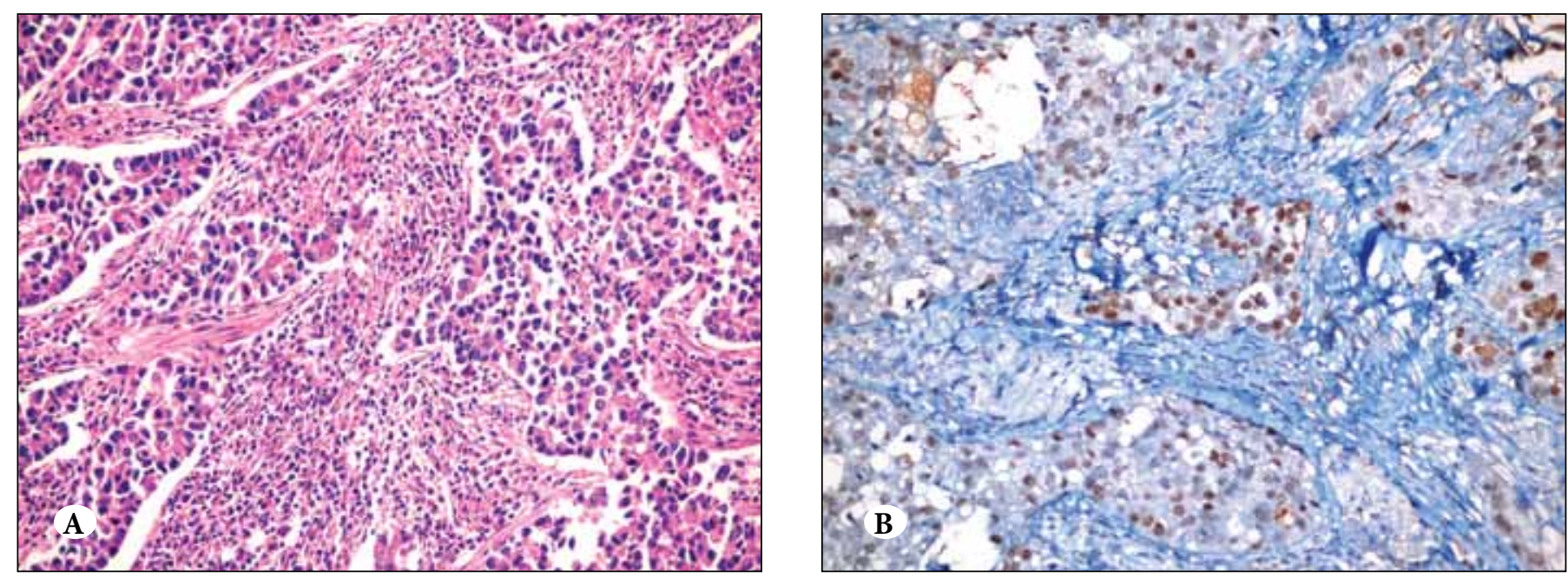

Figure 2: Adenocarcinoma. (A) Tumor cells were forming solid sheets, (H\&E, x20), (B) Tumor cells showed immunopositivity with TTF-1 (x20). 
Multiple neoplasms may occur at any age. However, in the reviewed literature the patients tend to be older than those with a single tumor (4). The reason for increased incidence of multiple neoplasms by age could be related with long exposure to environmental causative agents and more effective antitumor therapies that also prolong patients' lives and increase the risk of other primary neoplasms. Our patient was also from the older population and treated earlier with an aggressive anticancer medication.

Asbestos exposure is a well-recognized risk in the development of malignant mesothelioma. Epidemiological studies have demonstrated an increased risk of lung cancer by asbestos exposure but still the precise pathogenic mechanisms are unclear. The infrequency of reported co-existence

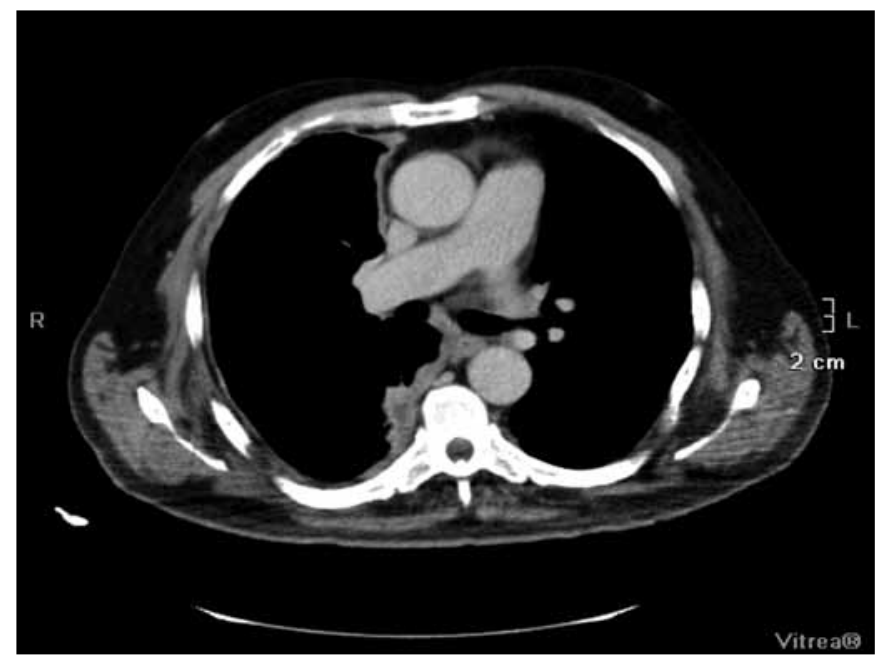

Figure 3: The mediastinal window of chest computerized tomography revealed pleural thickening with irregular internal margin at the right mediastinal pleura. of malignant mesothelioma and lung carcinoma suggests that the pathogenic mechanisms of asbestos-induced tumors could be different. It may also be related with the awareness of concomitant lung carcinoma because of the extensive mesothelioma.

The evidence of asbestos exposure can be determined from the patient history as occupation, macroscopic documentation as pleural plaques, microscopic identification of asbestos bodies in lung tissue and mineral analysis. In our patient, although the history was suspicious for asbestos exposure because of the house that he had been lived in during his childhood, we could not demonstrate any asbestos body by light microscopy in the lung tissue and any pleural plaque in his surgical specimens. It should also be kept in mind that the consensus statement from the International Mesothelioma Interest Group that defined the guidelines for pathologic diagnosis of malignant mesothelioma has pointed out the uselessness of the presence or absence of an asbestos history in making a diagnosis of mesothelioma (17).

In conclusion, a review of the existing data from the literature showed that the development of malignant pleural mesothelioma and lung carcinoma has infrequently been reported and could be associated with asbestos exposure. However, the history of asbestos exposure is not required for the diagnosis. Generally, a patient who developed one malignancy might be at greater risk of developing a second. This might be related with the initiating and promoting factors which probably still exist after occurrence of the first tumor. The influence of effective anticancer therapies which improve the survival rates and population ages could also be related. Further studies are needed to address the


Figure 4: Malignant mesothelioma. (A) Epithelioid tumor islands were encasing the lung parenchyma (H\&E, x2), (B) The tumor was diffuse positive with Calretinin (x2). 
potential of cancer patients being at higher risk of multiple primary tumors and to explain the causative agents.

\section{REFERENCES}

1. Berge T, Cederqvist L, Schonebeck J: Multiple primary malignant tumours. An autopsy study of a circumscribed population. Acta Pathol Microbiol Scand 1969,76:171-183

2. Haddow AJ, Boyd JF: Multiple primary neoplasms in the Western Hospital Region, Scotland: A survey based on cancer registration data. Scott Med J 1972, 17:143-152

3. Engin K: Cancers in multiple primary sites. Int Surg 1994, 79: 33-37

4. Aydiner A, Karadeniz A, Uygun K, Tas S, Tas F, Disci R, Topuz E: Multiple primary neoplasms at a single institution: Differences between synchronous and metachronous neoplasms. Am J Clin Oncol 2000, 23:364-370

5. Itil O: Akciger kanserlerinin epidemiyolojisi ve etiolojisi. In: Haydaroglu A. (Ed): Akciger Kanserleri, Tanı ve Tedavi. 1st ed., İzmir, Ege Üniversitesi Basımevi, 2000,15-34

6. Sozzi G, Miozzo M, Pastorino U, Pilotti S, Donghi R, Giarola M, De Gregorio L, Manenti G, Radice P, Minoletti F, Della Porta G, Pierotti MA: Genetic evidence for an independent origin of multiple preneoplastic and neoplastic lung lesions. Cancer Res 1995, 55:135-140

7. Leone G, Mele L, Pulsoni A, Equitani F, Pagano L: The incidence of secondary leukemias. Haematologica 1999, 84:937-945

8. Habal N, Sims C, Bilchik AJ: Gastrointestinal carcinoid tumors and second primary malignancies. J Surg Oncol 2000, 75:310-316
9. Matzkin H, Braf Z: Multiple primary malignant neoplasms in the genitourinary tract: Occurrence and etiology. J Urol 1989, 142: 1-12

10. Cagle PT, Wessels R, Greenberg SD: Concurrent mesothelioma and adenocarcinoma of the lung in a patient with asbestosis. Mod Pathol 1993, 6:438-441

11. Kishimoto T: A case of triple malignancies (gastric cancer, lung cancer and malignant pleural mesothelioma) after asbestos exposure. Nihon Kokyuki Gakkai Zasshi 2003, 41:304-309

12. Attanoos RL, Thomas DH, Gibbs AR: Synchronous diffuse malignant mesothelioma and carcinomas in asbestos-exposed individuals. Histopathology 2003, 43:387-392

13. Allen TC, Moran C: Synchronous pulmonary carcinoma and pleural diffuse malignant mesothelioma. Arch Pathol Lab Med 2006, 130:721-724

14. Lee AH, Soomro IN: Collision tumour of the pleura composed of small cell carcinoma and malignant mesothelioma. Histopathology 2004, 45:305-306

15. Bianchi C, Bianchi T, Ramani L: Malignant mesothelioma of the pleura and other malignancies in the same patient. Tumori 2007, 93:19-22

16. Warren S, Gates $O$ : Multiple primary malignant tumors: A survey of the literature and a statistical study. Am J Cancer 1932, 16: $1358-1114$

17. Husain AN, Colby TV, Ordonez NG, Krausz T, Borczuk A, Cagle PT, Chirieac LR, Churg A, Galateau-Salle F, Gibbs AR, Gown AM, Hammar SP, Litzky LA, Roggli VL, Travis WD, Wick MR: Guidelines for pathologic diagnosis of malignant mesothelioma: A consensus statement from the International Mesothelioma Interest Group. Arch Pathol Lab Med 2009, 133:1317-1331 